\title{
PENGARUH KREATIVITAS BERWIRAUSAHA, PRESTASI BELAJAR DAN EFIKASI DIRI TERHADAP MINAT BERWIRAUSAHA MAHASISWA
}

\author{
Maria Elen \\ e-mail: elenmaria606@gmail.com \\ Rusno \\ e-mail: rusno@unikama.ac.id \\ Udik Yudiono \\ e-mail: u_yudiono@unikama.ac.id
}

\begin{abstract}
(Program Studi Pendidikan Ekonomi, Fakultas Ekonomika dan Bisnis, Universitas Kanjuruhan, Malang)
\end{abstract}
\begin{abstract}
The purpose of the study was to reveal the effect of entrepreneurial creativity, learning achievement and self-efficacy on the interests of entrepreneurship in economic education students. Research using a quantitative approach to the type of research explanatory research. The population is 105 students. A sample of 58 students was determined using proportional random sampling. Data collection techniques using questionnaires and documentation. Based on the results of the analysis, several conclusions can be drawn including: there is an influence of entrepreneurial creativity, learning achievement and self-efficacy simultaneously have a positive effect on student interest in entrepreneurship seen from the F test with a significant value of $000<0.05$. Entrepreneurial creativity has a positive influence on students' entrepreneurial interest seen from the $F$ test with a significant value of $0.035<0.05$. Learning achievement has a positive influence on students' interest in entrepreneurship from the $F$ test with a significant value of $0.020<0.05$. selfefficacy has a positive effect on the entrepreneurial interest in entrepreneurship seen from the F test with a significance of $0.008<0.05$.
\end{abstract}

Keywords : Entrepreneurial Creativity, Learning Achievement, Self-Efficacy, Student Entrepreneurial Interest

\begin{abstract}
Abstrak: Tujuan penelitian untuk mengungkapkan pengaruh kreativitas berwirausaha, prestasi belajar dan efikasi diri terhadap minat berwirausaha mahasiswa pendidikan ekonomi. Penelitian menggunakan pendekatan kuantitatif dengan jenis penelitian explanatory research. Populasi berjumlah 105 mahasiswa. Sampel sebanyak 58 mahasiswa ditentukan menggunakan proportional random sampling. Teknik pengumpulan data menggunakan angket dan dokumentasi. Berdasarkan hasil analisis dapat ditarik beberapa kesimpulan diantaranya : ada pengaruh kreativitas berwirausaha, prestasi belajar dan efikasi diri berpengaruh positif secara simultan terhadap minat berwirausaha mahasiswa dilihat dari uji $F$ dengan nilai signifikan sebesar $000<0.05$. Kreativitas berwirausaha berpengaruh positif secara persial terhadap minat berwirausha mahasiswa dilihat dari uji $F$ dengan nilai signifikan sebesar $0.035<0.05$. prestasi belajar berpengaruh positif secara persial terhadap minat berwirausaha mahasiswa dilihat dari uji $F$ dengan nilai signifikan sebesar $0.020<0.05$. efikasi diri berpengaruh positif secara persial terhadap minat berwirausaha mahasiswa dilihat dari uji $F$ dengan signifikan sebesar $0.008<0.05$.
\end{abstract}

Kata kunci : Kreativitas Berwirausaha, Prestasi Belajar, Efikasi Diri, Minat Berwirausaha Mahasiswa 


\section{PENDAHULUAN}

Negara Indonesia merupakan salah satu negara yang memiliki jumlah angka pengangguran terbanyak. Angka pengangguran tersebut justru diciptakan oleh kelompok terdidik. Hal ini dikarenakan rendahnya minat masyarakat Indonesia untuk menciptakan lapangan pekerjaan. Masyarakat Indonesia cenderung lebih memilih mencari pekerjaan dibanding menciptakannya sehingga muncul permasalahan menyempitnya lapangan pekerjaan. Munculnya masalah tersebut mengakibatkan jumlah angka pengangguran semakin bertambah dan berdampak pada perekonomian negara Indonesia. Upaya untuk menyelesaikan permasalah tersebut telah dilakukan oleh berbagai pihak baik dari pemerintah, dunia pendidikan, maupun dunia industri.

Kreativitas sendiri memiliki arti yaitu kemampuan mengelola, memberdayakan, dan menggunakan pengetahuan apapun yang anda miliki, informasi, pengalaman, dan ketrampilan lainnya untuk mengatasi kesulitan (Hendro; 2011:17). Sehingga kreativitas berwirausaha merupakan kemampuan mahasiswa untuk mampu mengelola dan melahirkan sesuatu yang baru, ide-ide yang baru atau memanfaatkan barang yang sudah ada sebelumnya menjadi barang yang lebih berinovasi, yang relatif berbeda dengan apa yang telah dihasilkan.

Djamarah (2008:21) menyatakan bahwa prestasi adalah penilaian pendidikan tentang perkembangan dan kemajuan murid yang berkenaan dengan penguasaan bahan pelajaran yang disajikan kepada mereka dan nilai-nilai yang terdapat di dalam kurikulum. Jadi, prestasi belajar kewirausahaan merupakan hasil yang dicapai mahasiswa setelah melalui proses pembelajaran. Prestasi belajar mahasiswa terfokus pada nilai atau angka yang dicapai mahasiswa dimana dalam penelitian ini nilai yang dimaksud adalah nilai yang diperoleh dari mata kuliah kewirausahaan dan praktikum kewirausahaan.

Hisrich, Peters \& Sheperd (2008: 58) mendefinisikan "efikasi diri dalam kewirausahaan sebagai keyakinan diri yang merujuk pada perilaku seseorang yang dengan sukses dapat melaksanakan proses kewirausahaan". (the convicti on that one can successfully execute the entrepreneurial procces). Efikasi diri adalah kemampuan seseorang untuk menilai diri terhadap kemampuan dirinya untuk mengatur dan melaksanakan tindakan yang diperlukan untuk mencapai target yang ditetapkan dalam memulai sebuah usaha. Efikasi diri merupakan sesuatu yang mampu untuk memotivasi mahasiswa dari dalam dengan melihat masalah yang ada, maka mahasiswa termotivasi untuk berfikir kritis untuk menjadikan peluang.

Mahasiswa yang memiliki efikasi diri akan mampu menilai diri dan yakin akan kemampuan dirinya sendri dengan melihat dan berfikir kritis dan akan terdorong untuk mengambil langkah bisnis dengan melihat peluang.Efikasi diri dimahasiswa program studi Pendidikan Ekonomi Universitas Kanjuruhan Malang, terlihat masih kurang karena banyak mahasiswa kurang berfikir kritis dan tidak percaya kepada kemampuan dirinya sendri walaupun sudah melihat peluang didepan mata.Kondisi tersebut kurang mencerminkan mahasiswa yang mandiri dan percaya diri. Berdasarkan latar belakang yang telah diuraikan, maka peneliti tertarik untuk meneliti dan menganalisis permasalahan ini ke dalam sebuah skripsi yang berjudul " Pengaruh kreativitas berwirausaha, prestasi belajar kewirausahan dan efikasi diri terhadap minat berwirausaha mahasiswa Pendidikan Ekonomi Universitas Kanjuruhan Malang".

\section{TINJAUAN PUSTAKA}

\section{Minat Berwirausaha}

Minat pada dasarnya adalah suatu penerimaan akan suatu hubungan antara diri sendiri dengan luar diri. Semakin kuat atau dekat suatu hubungan tersebut, semakin besar minat (Slameto, 2013 :180). Sedangkan menurut Aprilia, dkk (2012:2) minat dapat dikatakan sebagai unsur keinginan 
dan ketertarikan seseorang terhadap sesuatu. Sedangkan menurut Alma (2010:26) kewirausahaan adalah proses menciptakan sesuatu yang lain dengan menggunakan waktu dan kegiatan yang disertai modal dan resiko serta menerima balas jasa dan kepuasan serta kebebasan pribadi. Yang dimaksud dengan minat berwirausaha adalah keinginan dan dorongan, untuk perbuatan yang mengarahkan diri manusia untuk berinteraksi, dan menciptakan sesuatu yang baru dengan perasaan senang untuk mencapai suatu tujuan.

\section{Kreativitas Berwirausaha}

Menurut Rusdiana (2014:95) mendefinisikan kreativitas sebagai kemampuan untuk mengembangkan ide-ide baru dan menemukan cara-cara baru dalam melihat masalah dan peluang. Menurut Sugihartono dkk (2013:14) menyatakan kreativitas sering melibatkan kemampuan berfikir. Orang yang kreatif dalam berfikir mampu memandang sesuatu dari sudut pandang yang baru serta mampu menghasilkan sesuatu yang baru dan berbeda. .". Menurut suryana (2013:12) berwirausaha adalah suatu pekerjaan yang mampu merencanakan, mengambil resiko, keputusan, dan tindakan untuk mencapai tujuan seorang wirausaha harus memiliki rasa percaya diri yang tinggi demi mencapai keberhasilan. Menyambung dari pengertian kreativitas diatas, maka kreativitas berwirausaha yaitu kemampuan seseorang dalam menciptakan produk atau jasa yang baru dan berbeda sehingga memiliki ciri tersendiri serta dapat berguna bagi masyarakat.

\section{Prestasi Belajar Kewirausahaan}

Prestasi belajar adalah tingkat keberhasilan siswa mencapai tujuan yang telah ditetapkan dalam sebuah program Muhibbin (2010:139). Purwanto (2010:85) berpendapat bahwa "belajar adalah perubahan dalam tingkah laku, dimana perubahan itu dapat mengarah kepada tingkah laku yang lebih baik, tetapi juga ada kemungkinan mengarah kepada tingkah laku yang lebih buruk". Dari pengertian diatas maka dapat disimpulkan bahwa prestasi belajar mahasiswa terfokus pada nilai atau angka yang dicapai mahasiswa dalam proses pembelajaran di kampus. Nilai tersebut dilihat oleh dosen untuk mengukur penguasaan pengetahuan mahasiswa. Pengertian prestasi belajar yang dimaksud dalam penelitian ini yaitu ditujukan pada nilai matakuliah kewirausahaan dan praktikum kewirausahan.

\section{Efikasi Diri}

Hisrich, Peters \& Sheperd (2008: 58) mendefinisikan "efikasi diri dalam kewirausahaan sebagai keyakinan diri yang merujuk pada perilaku seseorang yang dengan sukses dapat melaksanakan proses kewirausahaan". (the convicti on that one can successfully execute the entrepreneurial procces). Menurut (Hussein 2017:88) efikasi diri adalah sikap seseorang pegawai yang berhubungan dengan keyakinan pribadi mengenai kompetensi dan kemampuan diri dengan melaksanakan tugas.

\section{METODE}

Jenis penelitian yang digunakan adalah explanatory research yang bertujuan untuk menjelaskan kedudukan setiap variabel. Penelitian telah dilaksanakan di Pendidikan Ekonomi Universitas Kanjuruhan Malang. Populasi pada penelitian ini yaitu mahasiswa pendidikan ekonomi yang berjumlah 105 dan sampel penelitian berjumlah 58 mahasiswa yang diambil menggunakan dengan teknik proportional random sampling. proportional random sampling yaitu teknik pengambilan sampel penelitian dari setiap strata atau wilayah ditentukan seimbang atau sebanding 
dengan banyaknya subjek dari masing-masing strata atau wilayah. Variabel dalam penelitian ini terdiri dari tiga variabel bebas (independent variable) yaitu kreativitas berwirausaha, prestasi belajar kewirausahaan dan efikasi diri, sedangkan variabel terikatnya (dependent variable) yaitu minat berwirausaha

\section{HASIL DAN PEMBAHASAN}

Berdasarkan permasalahan tersebut, analisis kontribusi kreativitas berwirausaha, prestasi belajar dan efikasi diri terhadap minat berwirausaha mahasiswa. Berikut ini adalah hasil analisis data dan pengujian hipotesis yang telah dilakukan.

Berdasarkan hasil perhitungan dapat diketahui nilai: $a=3,541, b 1=, 223$ b2 $=5.303, b 3=, 463$ maka dapat disusun persamaan regresi linear berganda sebagai berikut:

$$
\begin{gathered}
Y=a+b 1 X 1+b 2 X 2+e \\
Y=3,541+0,223(X 1)+5,303(X 2)+0,463(X 3)
\end{gathered}
$$

Penjelasan dari persamaan regresi tersebut sebagai berikut:

1. Konstanta sebesar 3,541 memiliki arti jika variabel $\mathrm{X} 1, \mathrm{X} 2$ dan $\mathrm{X} 3$ atau jika variabel $\mathrm{X} 1, \mathrm{X} 2$ dan X3 bernilai nol, maka nilai variabel dependen (Y) akan sebesar 3,541.

2. Nilai koefisien regresi variabel X1 (kreativitas) sebesar 0,223 , artinya jika variabel X1 ditingkatkan 1 akan menyebabkan peningkatan minat berwirausaha sebesar 0,223.

3. Nilai koefisien regresi variabel X2 (prestasi belajar kewirausahaan) sebesar 5,303, artinya jika variabel X2 ditingkatkan 1 akan menyebabkan peningkatan minat berwirausaha sebesar 5,303 .

4. Nilai koefisien regresi variabel X3 (efikasi diri) sebesar 0,463, artinya jika variabel X3 ditingkatkan 1 akan menyebabkan peningkatan minat berwirausaha sebesar 0,463.

Jika dilihat dari nilai hasil analisis uji $\mathrm{F}$ didapat statistik nilai $\mathrm{F}$ sebesar 7.538 dengan tingkat signifikan 0,000 karena tingkat signifikan lebih kecil dari 0,05, maka hasil penelitian ini menolak hipotesis penelitan Ho1 dan menerima hipotesis penelitian Ha1 yaitu ada pengaruh yang signifikan secara simultan antara kreativitas berwirausaha, prestasi belajar dan efikasi diri terhadap minat berwirausaha.

Nilai Koefisien Determinasi (R Square) menunjukkan besarnya pengaruh seluruh variabel bebas yaitu kreativitas berwirausaha (X1), prestasi belajar (X2), dan efikasi diri (X3) terhadap minat berwirausaha (Y), jadi (R Square) 0,295 memiliki makna kreativitas berwirausaha, prestasi belajar dan efikasi diri mampu memberikan kontribusi sebesar 29,5\% terhadap minat berwirausaha (Y) dengan demikian sisanya 70,5\% dipengaruhi oleh variabel lain yang tidak termasuk dalam penelitian ini. misalnya : pengaruh jiwa berwirausaha, pendidikan kewirausahaan, motivasi dan lingkungan keluarga.

Untuk mengetahui pengujian hipotesis pertama, maka menggunakan uji $\mathrm{F}$ dan untuk menguji hipotesis ke dua, tiga, dan empat menggunakan uji t.

\section{Pengaruh kreativitas berwirausaha, prestasi belajar dan efikasi diri terhadap minat berwirausaha}

Hasil statistik menunjukkan bahwa ada pengaruh yang signifikan kreativitas berwirausaha, prestasi belajar dan efikasi diri terhadap minat berwirausaha. Hal ini dibuktikan dari hasil analisis uji F didapat statistik nilai F sebesar 7.538 dengan tingkat signifikan 0,000 karena tingkat signifikan lebih kecil dari 0,05, maka hasil penelitian ini menolak hipotesis penelitian Ho1 dan menerima hipotesis 
penelitian $\mathrm{H} 1$ yaitu: ada pengaruh yang signifikan secara simultan antara kreativitas berwirausaha, prestasi belajar dan efikasi diri terhadap minat berwirausaha.

\section{Pengaruh kreativitas berwirausaha terhadap minat berwirausaha}

Hasil analisis statistik menunjukkan bahwa ada pengaruh yang signifikan antara kreativitas berwirausaha terhadap minat berwirausaha. Hal ini dibuktikan dari hasil analisis uji t untuk variabel X1 (kreativitas berwirausaha) sebesar 2.158 dengan tingkat signifikan sebesar 0,035. Karena tingkat signifikannya lebih kecil dari 0,05, maka variabel X1 ( kreativitas berwirausaha) berpengaruh terhadap variabel $\mathrm{Y}$ (minat berwirausaha). Sehingga $\mathrm{H} 2$ diterima dan Ho2 ditolak.

\section{Pengaruh prestasi belajar terhadap minat berwirausaha}

Hasil analisis statistik menunjukkan bahwa ada pengaruh yang signifikan antara prestasi belajar terhadap minat berwirausaha. Hal ini dibuktikan dari hasil analisis uji t untuk variabel X2 (prestasi belajar) sebesar 2.405 dengan tingkat signifikan sebesar 0,020. Karena tingkat signifikannya lebih kecil dari 0,05, maka variabel X2 (prestasi belajar) berpengaruh terhadap variabel Y (minat berwirausaha). Sehingga $\mathrm{H} 2$ diterima dan $\mathrm{Ho} 2$ ditolak.

Pengaruh efikasi diri terhadap minat berwirausaha

Hasil analisis statistik menunjukkan bahwa ada pengaruh yang signifikan antara efikasi diri terhadap minat berwirausaha. Hal ini dibuktikan dari hasil analisis uji $\mathrm{t}$ untuk variabel X3 (efikasi diri) sebesar 2.735 dengan tingkat signifikan sebesar 0,008. Karena tingkat signifikannya lebih kecil dari 0,05, maka variabel X3 (efikasi diri) berpengaruh terhadap variabel Y (minat berwirausaha). Sehingga $\mathrm{H} 2$ diterima dan $\mathrm{Ho} 2$ ditolak.

\section{KESIMPULAN}

Berdasarkan hasil analisis yang telah dikemukakan pada bab VI, maka dapat ditarik beberapa kesimpulan sebagai berikut: (1) terdapat pengaruh yang signifikan secara simultan kreativitas berwirausaha, prestasi belajar dan efikasi diri terhadap minat berwirausaha. (2) terdapat pengaruh yang signifikan secara persial kreativitas berwirausaha terhadap minat berwirausaha. (3) terdapat pengaruh yang sifnifikan secara persial prestasi belajar terhadap minat berwirausaha. (4) terdapat pengaruh yang signifikan secara persial efikasi diri terhadap minat berwirausaha

\section{DAFTAR PUSTAKA}

Alma. Buchari. (2010). Kewirausahaan. Bandung : Alfabeta.

Aprilia, Fitriani, Harmanik. (2012). Faktor-Faktor yang Mempengaruhi Minat Berwirausaha Pada

Siswa Kelas XII SMK Negri 1 Kandeman Kabupaten Batang Tahun 2011/2012. http://lib.unnes.ac.id/13922/ Diakses 17 agustus 2018

Djamarah. Bahri. S. (2008). Psikilogi Belajar. Jakarta : Rin Eka Cipta.

Hendro . (2011). Dasar-Dasar Kewirausahaan. Jakarta: Erlangga

Hisrich, Peters, \& Shepherd. (2008). Entrepreneurship 7th Edition. New York:McGraw-Hill

Hussein, Fattah. (2017). Kepuasan Kerja dan Kinerja Pegawai, Budaya Organisasi, Perilaku Pemimpin dan Efikasi Diri. Yogyakarta: Elmatera.

Muhibbin Syah .(2010). Psikologi Pendidikan dengan pendekatan baru. Bandung:PT Remaja Rosdakarya

Rusdiana, H.A. (2014). Kewirausahaan Teori \& Praktik. Bandung: CV.Pustaka Setia 
Sugirhartono dkk. (2013). Psikologi Pendidikan. Yogyakarta: UNY Press.

Suryana. (2013). Kewirausahaan; Kiat Dan Proses Menuju Sukses. Salemba Empat. Jakarta.

Slameto, (2013) Belajar dan Faktor-faktor yang Mempengaruhi, Edisi Revisi. Jakarta :Rineka Ciptas

Purwanto, Ngalim M. (2010). Psikologi Pendidikan edisi revisi. Bandung : Remaja Rosdakarya. 